\title{
Impact of sustainable tillage on biophysical properties of Planosol and on faba bean yield
}

\author{
Kęstutis Romaneckas, Rasa Kimbirauskienè, Aida Adamavičienė, Sidona Buragienė, Aušra Sinkevičienė, Egidijus \\ Šarauskis, Algirdas Jasinskas and Aleksandra Minajeva \\ Vytautas Magnus University, K. Donelaičio str. 58, 44248 Kaunas, Lithuania \\ e-mail: kestutis.romaneckas@vdu.It
}

\begin{abstract}
Decreased tillage intensity can contribute to a reduced agro-technological footprint and stabilise the negative impact of climate change, especially in leguminous crop cultivation. For this reason, a long-term (since 1988) stationary field experiment has been performed on silty loam Planosol (in Lithuania). The main objective of this study was to establish the influence of sustainable tillage and no-tillage systems on soil aggregate stability to water, penetration resistance, enzymatic activity, abundance of earthworm and faba bean grain yield. Five different tillage systems were investigated: conventional deep and shallow mouldboard ploughing, deep chiselling, shallow disking and notillage. No-tillage in faba bean cultivation significantly increased soil structural stability by $40-97 \%$, saccharase content by $0.7-2.0$ times, urease activity by $3-4$ times, the average quantity of earthworm by $55 \%$ and the biomass by 3.6 times. The impact of other ploughless tillage systems on soil properties was positive but not as significant. Faba bean grain yield was more influenced by growing seasons than by different tillage methods.
\end{abstract}

Key words: cold climate, tillage systems, soil properties, grain yield, Vicia faba

\section{Introduction}

During the last 20-30 years, ploughless tillage technologies have become prevalent inculcated. In some European countries, this practise has reached more than 70\% (Alvarez and Steinbach 2009). According to Cannell (1985), shallow tillage can be a good practise as mouldboard ploughing in most countries on a wide range of soil types. No-tillage (NT) or zero tillage technology is the marginal technology, which uses new machinery, higher amounts of pesticides and so on. Despite that, it is currently used on more than one million hectares in Europe (Lopez et al. 2012). Ploughless or no-tillage systems may reduce technological costs, prevent soil moisture and fertility losses due to erosions, promote $\mathrm{CO}_{2}$ sequestration, stabilise crop productivity and energy use (Morris et al. 2010, Rusu et al. 2011, Soane et al. 2012, Arvidsson et al. 2013, Lozano-García and Parras-Alcántara 2014, Šarauskis et al. 2014, Kazemi et al. 2015). Kertész and Madarász (2014) points out that risk of soil erosion varies according to the different ecological regions in Europe. In the Northern countries, in cold climate conditions, risks of soil erosion are lower compared to the semi-arid Mediterranean regions are lower. However, the Lithuanian climate is quite unstable and has scattered distribution of precipitation. Precipitation rates are sometimes surplus, therefore, on the average $70 \%$ of the total soil and $17 \%$ of agricultural soil erodes (43-58\% in the hilly regions) (Jankauskas et al. 2008). The best way to mitigate the process of erosion is to increase the stability of soil structure through sustainable tillage practises (Rasmussen 1999).

The activity of soil enzymes is one of the most important soil biological activities (mainly reflecting the amount of microorganisms) and fertility indicators (Mikhailovskaya and Tarasčuk 2008). The production of enzymes during the vegetation period depends on temperature, soil moisture, availability of nutrients and abundance of earthworms (Tao et al. 2009, Guenet et al. 2012), all of which highly depend on the applied tillage systems (Lukošiūnas and Germanas 2006, Bogužas et al. 2010).

Faba bean maintains the sustainability of agricultural systems due to efficient symbiotic fixation of atmospheric nitrogen (Karkanis et al. 2018). According to the Ntatsi et al. (2018) investigations, the total amount of biologically fixed $\mathrm{N}$ in faba bean crop varied from 118.5 to $193.9 \mathrm{~kg} \mathrm{ha}^{-1}$ depending on the various cropping systems and cultivars. The amount of $\mathrm{CO}_{2}$ respiration from the root systems is higher than $\mathrm{CO}_{2}$ generation during $\mathrm{N}$-fertilizer production. Besides, faba bean crop emits approximately 4-5 times less $\mathrm{N}_{2} \mathrm{O}$ per growing season than alfalfa or soybean, 5 times less than fertilized wheat or maize crop, and 10 times less than fertilised pasture. Therefore, developing faba bean cultivation areas may decrease greenhouse gas (GHE) emissions (Jensen et al. 2012).

Sustainable tillage technologies have been widely investigated, but there are very few studies on faba bean crop. The results from over 18 years of investigations in the Mediterranean climate conditions showed that no-tillage (NT) 
system decreased the costs and prevented the negative impacts of tillage on the physical, chemical and biological properties of the soil. The success of NT depends on the effectiveness of weed control (Giambalvo et al. 2012).

The EU Greening program requested increasing the area of leguminous crops. The Lithuanian conditions are the most favourable for pea and faba bean growing, and the area of these crops have increased about 20 times. Sustainable tillage technologies have been used in approximately $40 \%$ of Lithuanian agricultural land. Our previous investigations showed that, long-term sustainable soil tillage systems were effective for winter wheat, barley, oilseed rape, maize, and sugar beet (Romaneckas et al. 2006, Romaneckas et al. 2009, Romaneckas et al. 2019). Thus, as with other crops, changing tillage intensity from conventional reversible deep ploughing to chiselling, disking or no-tillage (direct drilling) can be expected to reduce the risk of soil degradation and conserve faba bean productivity in unstable boreal semi humid climate conditions.

\section{Material and methods}

\section{Site description}

The long-term stationary field experiment was performed at the Experimental Station of Vytautas Magnus Univer-

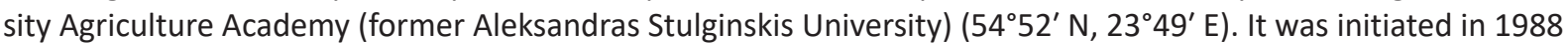
and modified in 2001, when a direct sowing treatment was added. The research data, presented in this article, is from $2016-2018$. The soil in the experimental field was silty loam (45.6\% sand, $41.7 \%$ silt, $12.7 \%$ clay) Planosol (WRB 2014). The depth of the arable layer was $25-27 \mathrm{~cm}$. The $\mathrm{pH}_{\mathrm{KCL}}$ of the soil surface was 6.4-7.7, the amount of available phosphorus varied from 194 to $384 \mathrm{mg} \mathrm{kg}^{-1}$ and potassium from 85 to $206 \mathrm{mg} \mathrm{kg}^{-1}$. The variation and location of elements depended on long-term soil tillage practices.

The climate of the experimental site is identified as boreal (subarctic). During the last 100 years, the average annual temperature increased from 6.3 to $6.7^{\circ} \mathrm{C}$, precipitation rate from 590 to $625 \mathrm{~mm}$. The precipitation varied from $39.6 \%$ (December) to $66.7 \%$ (October). The length of vegetation season with active temperatures (SAT, $\geq 10$ ${ }^{\circ} \mathrm{C}$ ) is approximately 6 months. The SAT in 1990 was $2132{ }^{\circ} \mathrm{C}$, in $1995-2371{ }^{\circ} \mathrm{C}$ and in $2018-2965{ }^{\circ} \mathrm{C}$. The average of air temperatures across 24 hours and the precipitation rates are presented in Table 1 and 2.

Table 1. Average air temperature across 24 hours during faba bean vegetative seasons, Kaunas Meteorological Station

\begin{tabular}{ccccccc}
\hline Year/ Month & April & May & June & July & August & September \\
\hline 2016 & 7.4 & 15.7 & 17.2 & 17.9 & 16.9 & 17.5 \\
2017 & 5.6 & 12.9 & 15.4 & 16.8 & 13.4 \\
2018 & 10.2 & 17.2 & 17.5 & 20.1 & 19.2 & 17.3 \\
$\begin{array}{c}\text { Long-term (1974-2017) } \\
\text { average }\end{array}$ & 6.9 & 13.2 & 16.1 & 18.7 & 12.6 \\
\hline
\end{tabular}

Table 2. Rainfall (mm) during faba bean vegetative seasons, Kaunas Meteorological Station

\begin{tabular}{ccccccc}
\hline Year/ Month & April & May & June & July & August & September \\
\hline 2016 & 41.2 & 36.4 & 83.9 & 162.9 & 114.9 & - \\
2017 & 73.7 & 10.5 & 80.2 & 79.6 & 55.0 & 96.6 \\
2018 & 64.8 & 17.6 & 57.6 & 137.5 & & \\
$\begin{array}{c}\text { Long-term (1974-2017) } \\
\text { average }\end{array}$ & 41.3 & 61.7 & 76.9 & 96.6 & 88.9 & 60.0 \\
\hline
\end{tabular}

The beginning of the 2016 vegetative season was warmer than usually, with slightly lower precipitation rates. July and August were colder and much wetter. The vegetative season of 2017 might be characterized as colder than the long-term average, but with uneven distribution of precipitation. For example, April was excessively humid and May was extremely dry. All of the vegetative season of 2018 was warmer than usual. The distribution of precipitation was uneven. Similarly to 2017, May was droughty, but July and August were excessively humid.

The increase of air temperatures is a positive tendency for crop productivity realization; however, higher temperatures and rising of precipitation rates lead to destruction of soil aggregates, increased soil compaction and reduced bioactivity (Karmakar et al. 2016, Juhola et al. 2017, Sengar and Sengar 2017). In our earlier experiments, we have 
K. Romaneckas et al. (2019) 28: 101-111

found that higher precipitation rates during maize vegetative period (May-September) had a negative impact on soil aggregate stability (SAS, aggregates $>1 \mathrm{~mm}$ ) to water $(r=-0.549)$ (Romaneckas et al. 2015). In preside experiment, we found similar tendencies ( $r=-0.540$ at $p \leq 0.05)$. However we found positive correlation between SAS and average temperatures during vegetative period (April-August) ( $r=0.658$ at $p \leq 0.01$ ).

\section{Experiment design and agricultural practices}

Five primary soil tillage systems were investigated: 1 . Deep mouldboard ploughing (DP = control treatment); 2 . Shallow mouldboard ploughing (SP); 3. Deep cultivation-chiselling (DC); 4. Shallow cultivation-disking (SC); 5. Notillage (direct sowing) (NT).

Crop rotation in the experiment: spring oilseed rape - winter wheat - maize (faba bean since 2016) - spring barley. The experiment was performed in 4 replications. There were 20 plots per crop in total. The initial size of the experimental plot was $126 \mathrm{~m}^{2}(14 \times 9 \mathrm{~m})$. Randomized design of plot's distribution was used. The buffer strip was $1 \mathrm{~m}$ wide between the experimental plots and $9 \mathrm{~m}$ between the blocks. After crop harvesting, all experimental plots (except NT) were disked with a Väderstad Carrier 300 disc harrow (Table 3).

Table 3. Tillage practice in the experiment (according to Romaneckas et al. 2017)

\begin{tabular}{|c|c|c|c|c|c|}
\hline Tillage system & Stubble tillage & Primary tillage & Implement & $\begin{array}{l}\text { Depth of tillage } \\
\qquad(\mathrm{cm})\end{array}$ & $\begin{array}{l}\text { Pre-crop residue cover } \\
\qquad(\%)\end{array}$ \\
\hline Deep ploughing & Yes & Inversion & Mouldboard plough & $22-25$ & $0-3$ \\
\hline Shallow ploughing & Yes & Inversion & Mouldboard plough & $12-15$ & $2-4$ \\
\hline Deep cultivation & Yes & Non-inversion & Chisel cultivator & $25-30$ & $40-51$ \\
\hline Shallow cultivation & Yes, twice & No & Disc harrow & $10-12$ & $40-50$ \\
\hline No-tillage & No & No & None & 0 & $47-87$ \\
\hline
\end{tabular}

The John Deere 6620 tractor was used in the experiment. According to the experimental scheme, the primary tillage was carried out between September and October (Table 4). Soil was ploughed with the traditional plough Gamega PP-3-43 (Lithuania) with semi-screw shell boards, deep chiselling was carried out with the KRG-3.6 (Lithuania) ridge cultivator (chisel). SC plots were additionally disked with a Väderstad Carrier 300 disk harrow. NT plots were not tilled at all. Before sowing, the soil was cultivated with Laumetris KLG-3.6 (Lithuania) cultivator (except NT). Seeds were sowed with Väderstad Rapid 300C Super XL drill and fertilised at the same time. Additional fertilisation of crop was performed with fertiliser spreader Amazone-ZA-M-1201. Pesticides were spread with spreader Amazone UF-901. Faba bean was sown when topsoil reached physical maturity (Table 4). Distance between rows was $25 \mathrm{~cm}$. The sowing rate was about 200-220 kg grain per ha (40-45 seeds per $\mathrm{m}^{2}$ ). The sowing depth was 5-6 $\mathrm{cm}$. Faba bean variety 'Fuego' (C2, mass of 1000 grain was $630 \mathrm{~g}$ ) was sown.

The variety was created by Norddeutsche Pflanzenzucht Hans-Georg Lembke KG, Germany. Before sowing, the seeds were inoculated with a Rhizobium leguminosarum bacterial preparation (approximately $200 \mathrm{ml}$ of preparation for $100 \mathrm{~kg}$ seeds) because, in poor soils bacterial preparations increase the productivity and quality of faba bean crop (Denton et al. 2013). Pests in faba bean cultivation were controlled the beginning of crop flowering (BBCH 60-63) (Table 4). The crop was harvested with Wintersteiger Delta (Austria) combine harvester.

Table 4. Technological operations and timing in faba bean growing technology

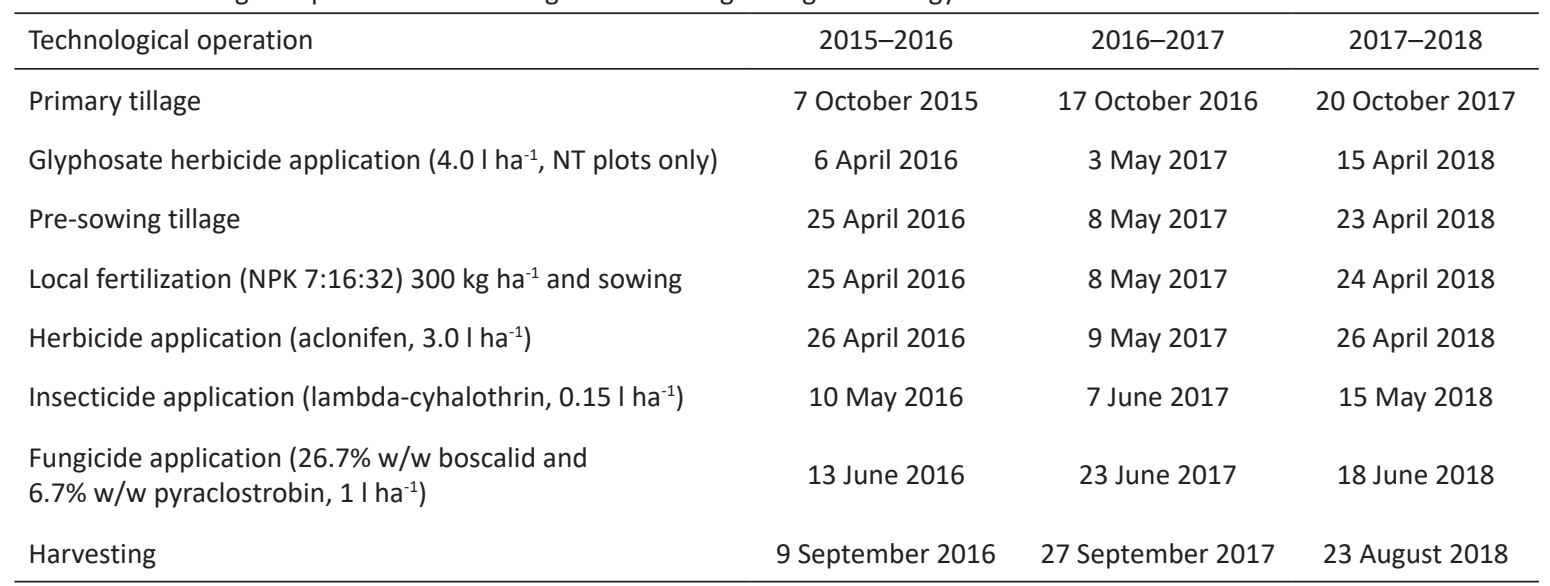




\section{Methods and analysis}

The projection coverage of the pre-crop (spring oilseed rape) residues was determined after the primary tillage and sowing (5 May 2016, 15 May 2017, 4 May 2018). The 10 m length metal strip was used for measuring. The points of contact with plant residues were set every $10 \mathrm{~cm}$ (100 times per plot).

Soil aggregate stability to water was determined in 0-15 cm layer in no less than five spots per plot before presowing tillage in spring (4 April 2016, 5 May 2017, 19 April 2018) and after the faba bean harvest (3 October 2016, 2 October 2017, 6 September 2018). For sieving, we used the wet-sieving methodology (Angers et al. 2006), using sieves with mesh diameters of $5-0.25 \mathrm{~mm}$.

Soil penetration resistance was measured 4 times during the vegetation of each vegetative period (6 April 2016, 27 April 2016, 14 June 2016, 13 September 2016; 5 April 2017, 19 May 2017, 27 June 2017, 6 October $2017 ; 17$ April 2018, 3 May 2018, 5 July 2018, 2 September 2018) in 0-50 cm layer, no less than 5 spots per plot, with penetrologer Eijkelkamp 06.15SA (Birs HydroMet GmbH).

Soil enzymatic activity was identified after faba bean harvest (3 October 2016, 2 October 2017, 6 September 2018) before primary soil tillage (in 0-15 cm layer). The activity of the soil enzyme urease was determined by the methods of Hofmann and Schmidt (1953), saccharase by Hofmann and Seegerer (1950) and Chunderova (1973).

The number of earthworms was established after faba bean harvesting before primary soil tillage ( 14 September 2016, 4 October 2017, 12 September 2018) at 3 spots per each plot in $0.25 \mathrm{~m}^{2}$ area. The investigation was based on the use of formalin extraction. A $0.5 \times 0.5 \mathrm{~m}$ metal frame was set to the ground to separate the area. A $0.5 \%$ formalin solution (not less than $8 \mathrm{I}$ ) was poured onto the ground in the frame (Clapperton et al. 2006). When the solution was absorbed, all earthworms on the surface of the soil were collected, counted and weighed.

Ten samples for faba bean biological yield of grain were taken from each plot of experiment in random spots (area $\left.0.25 \mathrm{~m}^{2}\right)$. Grains were dried and data recalculated to $15 \%$ moisture content.

The data was analysed using one-way ANOVA. The treatment effect was tested using the P test and least significant difference (LSD). The experimental data were also tested with SigmaStat and SigmaPlot software. Significant differences between treatments and the control were expressed by * - significant difference at the $95 \%$ probability level $(p \leq 0.05>0.01) ;{ }^{* *}$ - significant difference at the $99 \%$ probability level $(p \leq 0.01>0.001)$; and $p>0.05$ - no significant difference at the $95 \%$ probability level. Different letters within columns mean significant difference at $p \leq 0.05$.

\section{Results and discussion}

\section{Soil aggregate stability to water}

According to the data of our investigations, the top layer of the soil we had more than $50 \%$ of structural aggregates which proved high soil stability. According to the research of Köpke and Nemecek (2010), faba bean cultivation improved soil physical structure. Likewise, in our experiment, long-term non-inversion tillage systems significantly prevented the destruction of soil structural aggregates (Table 5). Similarly, our earlier investigations on maize cultivation found that non-reversibly tilled and NT plots had the highest stability of soil aggregates (Romaneckas et al. 2015).

Table 5. Effects of different tillage practice on soil aggregate stability to water (SAS, \%) (0-15 cm layer) before and after faba bean vegetative growth period

\begin{tabular}{|c|c|c|c|c|c|c|}
\hline \multirow[t]{2}{*}{ Tillage system } & \multicolumn{2}{|c|}{2016} & \multicolumn{2}{|c|}{2017} & \multicolumn{2}{|c|}{2018} \\
\hline & Before & After & Before & After & Before & After \\
\hline Deep ploughing & $46.8 \mathrm{~b}$ & $47.7 c$ & $35.9 b$ & $42.8 d$ & $49.4 c$ & $36.7 c$ \\
\hline Shallow ploughing & $49.9 b$ & $56.5 b c$ & $45.6 b$ & $44.7 \mathrm{~cd}$ & $55.0 \mathrm{bc}$ & $41.8 \mathrm{c}$ \\
\hline Deep cultivation & $60.6 * a$ & $53.7 c$ & $60.6 * a$ & $57.8 * b c$ & $63.7 * a b$ & $56.2 * * b$ \\
\hline Shallow cultivation & $63.9 * * a$ & $64.8^{* *} \mathrm{ab}$ & $65.0 * * a$ & $65.7 * * a b$ & $68.0 * * a$ & $57.9 * * b$ \\
\hline No-tillage & $65.4 * * a$ & $72.4 * * a$ & $70.6 * * a$ & $70.7^{* * a}$ & $72.7 * * a$ & $68.5^{* * a}$ \\
\hline $\mathrm{LSD}_{0.05}$ & 9.97 & 11.52 & 11.58 & 11.95 & 10.68 & 7.24 \\
\hline 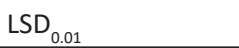 & 13.98 & 16.15 & 16.24 & 16.76 & 14.98 & 10.15 \\
\hline
\end{tabular}


In their study, Blanco-Canqui and Ruis (2018) concluded that NT increased wet soil aggregate stability by 1 to $97 \%$. In our presented experiment, during humid faba bean vegetative periods of 2016-2017, soil aggregate stability (SAS) after harvesting was mainly higher or similar than after wintering. However in droughty vegetative period of 2018, we found converse results. Moreira et al. (2016) results confirm that soil physical properties under NT are highly dynamic and influenced by soil disturbance at furrow opening, wetting and drying cycles and depth of sampling.

The stability of the soil aggregates to water was determined by differences in the amount of pre-crop (winter wheat) residues $(r=0.897$ and 0.906 at $p \leq 0.05)$. There was also a relationship between soil structural stability and number or biomass of earthworms ( $r=0.910$ and 0.902 at $p \leq 0.05)$.

\section{Soil penetration resistance}

In 2016, the highest soil penetration resistance before pre-sowing tillage in spring was determined in untreated plots (NT) (Fig.1a). The trend has been observed from the soil surface to the depth of $45 \mathrm{~cm}$. Other scientists confirm our findings (Bogunovic et al. 2018), but information from faba bean experiments is stills scarce. Only Badagliacca et al. (2018) established that the long-term continuous application of NT, compared to conventional tillage (CT), increases soil bulk density in faba bean cultivation. In the presented experiment, relatively hard soil was also observed in shallowly cultivated (disked, SC) plots, but even at the depth of $20 \mathrm{~cm}$, it was rather friable.
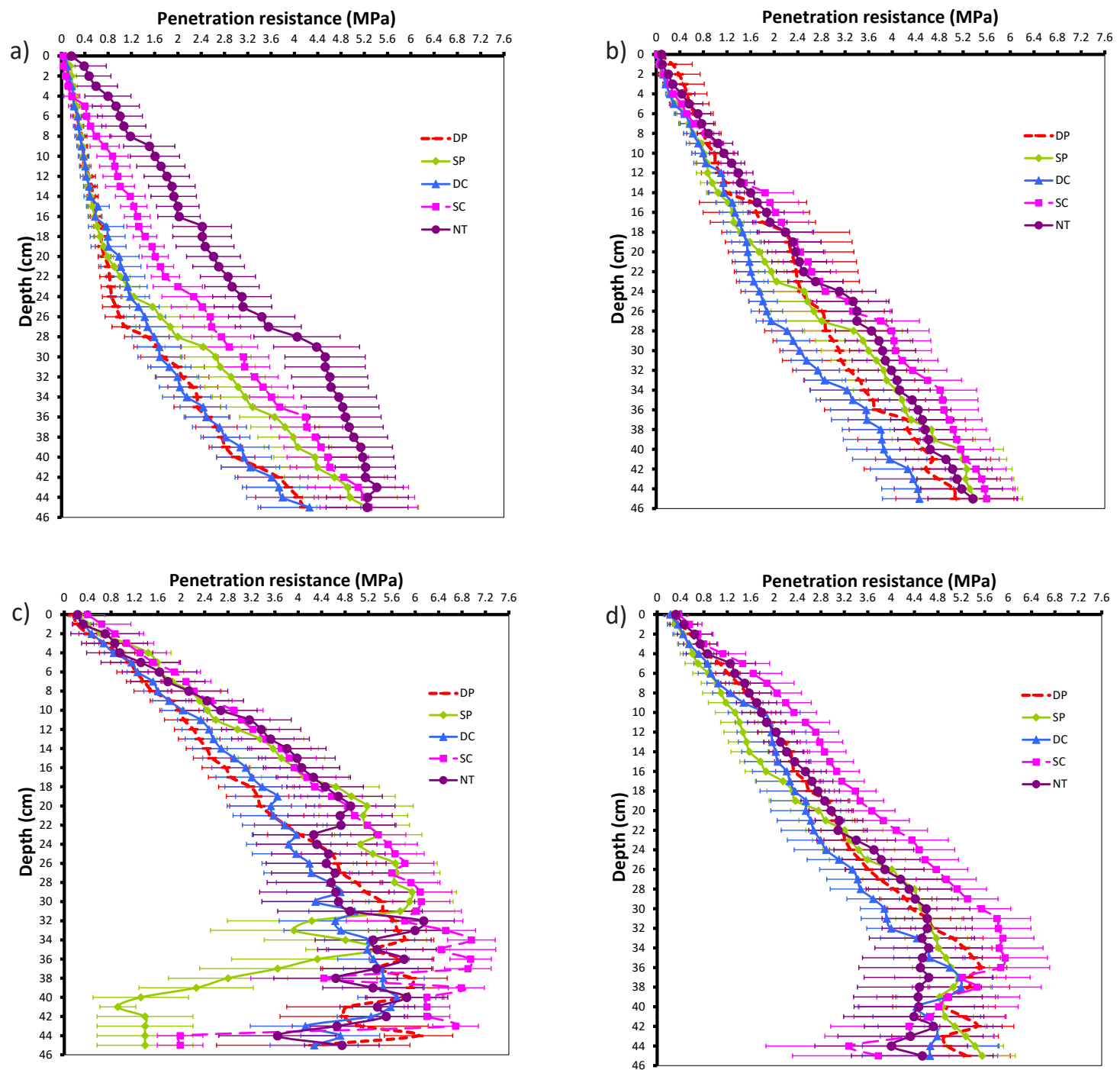

Fig. 1. Soil penetration resistance at different stages of experiment in 2016: a) before pre-sowing tillage in spring; b) after faba bean sowing; c) beginning of faba bean flowering; d) after harvesting. DP = deep ploughing, SP = shallow ploughing, $\mathrm{DC}=$ deep cultivation, $\mathrm{SC}=$ shallow cultivation, NT = no-tillage (direct drilling). Horizontal bars mean standard deviation.

The penetration resistance of the shallowly ploughed (SP) plots from the depth of $24 \mathrm{~cm}$ began to increase. The penetration resistance of the deeply ploughed (DP) and deeply cultivated (DC) plots was the lowest, and, even at a depth of $25 \mathrm{~cm}$, the soil was classified as loose. During sowing, the soil surface was slightly compressed, but remained friable (Fig. 1b). 
Much viewable differences of soil penetration resistance were observed at the depth of $14-16 \mathrm{~cm}$. Soil of NT and SC plots remained harder and the most friable soil profile was in DC plots. In spite of this, at the depth of about $15 \mathrm{~cm}$, the soil remained fluffy and in $25 \mathrm{~cm}$ it was hard. Such conditions are favourable to the development of most agricultural plants.

At the stage of faba bean flowering, the soil hardened significantly due to lack of precipitation (Fig. 1c). Only up to a depth of $6 \mathrm{~cm}$, this soil was attributed as fluffy, and at a depth of $15 \mathrm{~cm}$ it was already hard, except for DP and DC plots. During the faba bean vegetation, SC plots became the hardest, and the penetration resistance of soil in DP, SP and NT plots became similar (Fig. 1d). DC plots had less penetration resistance in the soil layer of about 22-32 cm depth. Therefore, if the soil is cultivated this way, the roots of the beans fall deep and use nutrients and water deeper.

The climatic conditions in 2017 were more humid than in 2016, and the soil was characterised as having a lower penetration resistance, especially at the beginning of vegetation. Prior to soil tillage in spring and after sowing, the highest soil penetration resistance was observed in NT plots (Fig. 2a and 2b). Nevertheless, the penetration resistance of the arable layer did not exceed $2 \mathrm{MPa}$ and was friable; therefore, it did not interfere with the development of deep bean roots. At the time of faba bean flowering, the soil had dried up and its penetration resistance had increased, especially in the subsoil. The highest penetration resistance remained in the NT plots (Fig. 2c). After harvesting, a lot of precipitation fell, so the total penetration resistance of the soil decreased, the differences between the variants equalised, but DP soil remained the most friable (Fig. $2 \mathrm{~d}$ ).
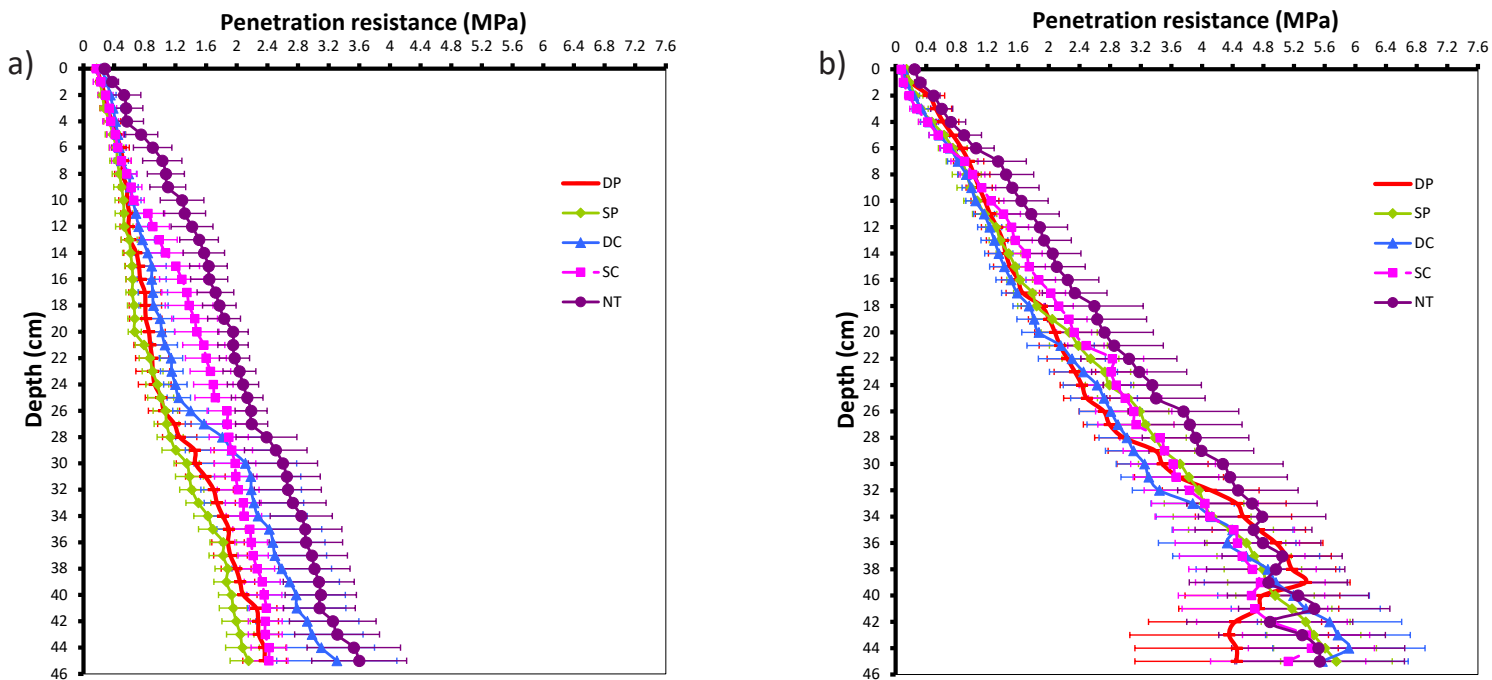

C) Penetration resistance (MPa)

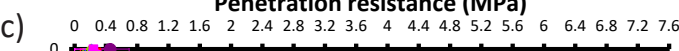

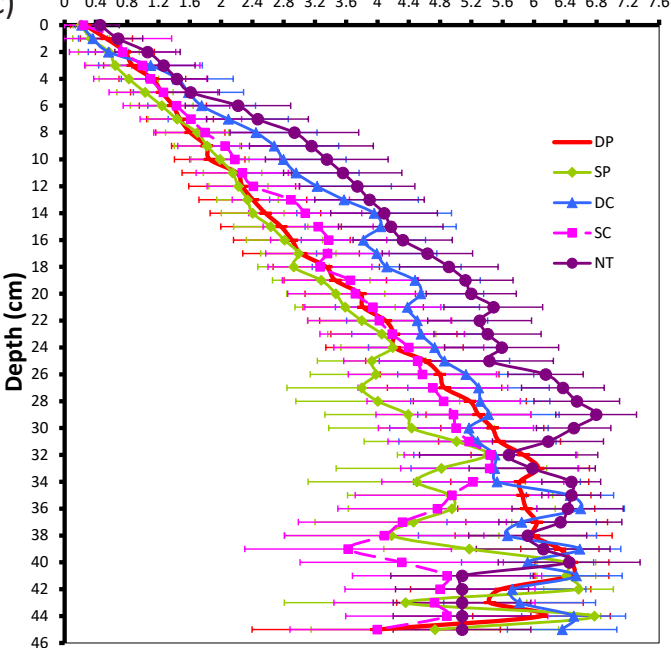

Penetration resistance (MPa)

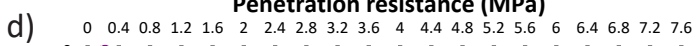

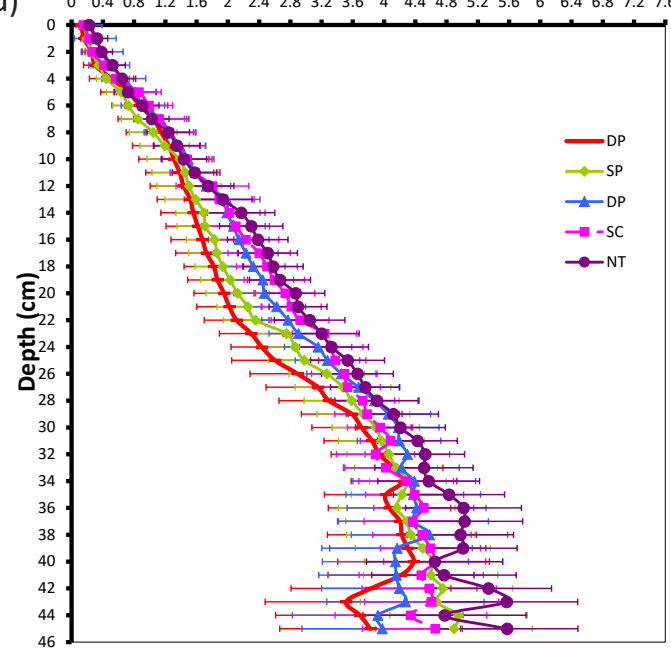

Fig. 2. Soil penetration resistance at different stages of experiment in 2017: a) before pre-sowing tillage in spring; b) after faba bean sowing; c) beginning of faba bean flowering; d) after harvesting. DP = deep ploughing, SP = shallow ploughing, $\mathrm{DC}=$ deep cultivation, $\mathrm{SC}=$ shallow cultivation, $\mathrm{NT}=$ no-tillage (direct drilling). Horizontal bars mean standard deviation. 
The climatic conditions during 2018 vegetation were more arid and warmer than in the previous experimental years, but after winter, at the beginning of vegetation, moisture in the soil was sufficient and the penetration resistance was low (Fig. 3a and 3b). Unlike 2016 and 2017, in 2018 the soil remained quite fluffy during the whole bean vegetation, with only the subsoil hardening more. There were also no major differences in penetration resistance between tillage treatments, but in the middle and at the end of the vegetation, DP soil subsoil became harder (Fig. 3c and 3d). In Blanco-Canqui and Ruis (2018) experiments, NT had mixed effects on penetration resistance as well.
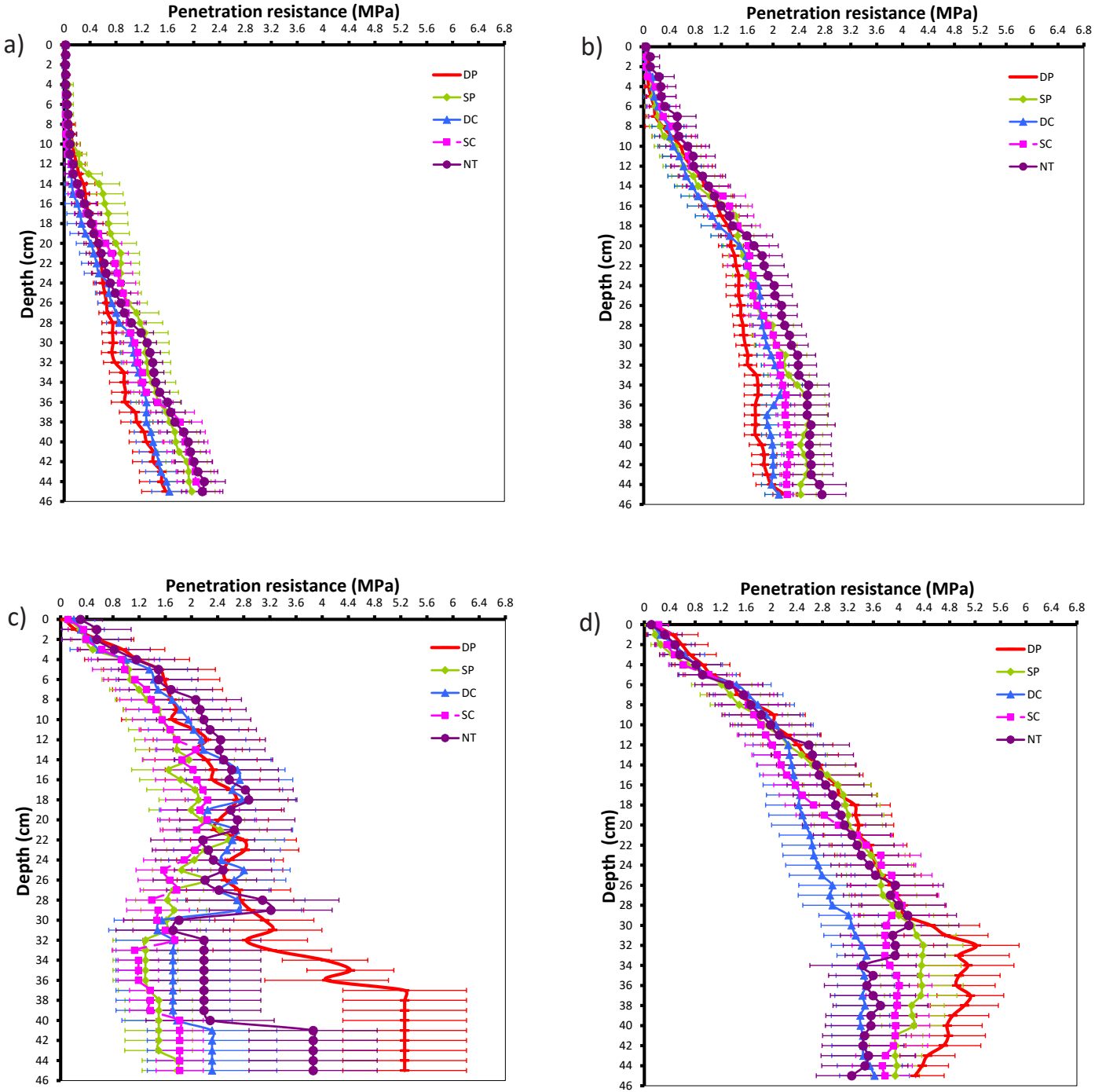

Fig. 3. Soil penetration resistance at different stages of experiment in 2018: a) before pre-sowing tillage in spring; b) after faba bean sowing; c) beginning of faba bean flowering; d) after harvesting. DP = deep ploughing, SP = shallow ploughing, $\mathrm{DC}=$ deep cultivation, $\mathrm{SC}=$ shallow cultivation, $\mathrm{NT}$ = no-tillage (direct drilling).

\section{Soil enzymatic activity}

Our research suggests that reducing of soil tillage intensity from annual DP to other alternatives and NT, soil enzymes steadily increase (Table 6). Essentially, the highest enzyme activity was found in NT plots. The activity of saccharase was almost 0.7-2.0 times higher and urease was approximately 3-4 times higher than in DP plots. Activity of saccharase was closely related with activity of urease $(r=0.889$ at $p \leq 0.01)$. Besides, we found that average temperatures during vegetative period (April-August) had higher impact $\left(r_{\text {saccharase }}=0.636\right.$ and $r_{\text {urease }}=0.590$ at $p \leq 0.05)$ on soil enzymatic activity than precipitation rates $(p>0.05)$. 
Table 6. Effect of different tillage practise on soil enzymatic activity

\begin{tabular}{|c|c|c|c|c|c|c|}
\hline \multirow[t]{2}{*}{ Tillage system } & \multicolumn{3}{|c|}{ Saccharase (mg glucoses $1 \mathrm{~g}$ of soil per $48 \mathrm{~h}$ ) } & \multicolumn{3}{|c|}{ Urease (mg $\mathrm{NH}_{3} 1 \mathrm{~g}$ of soil per $24 \mathrm{~h}$ ) } \\
\hline & 2016 & 2017 & 2018 & 2016 & 2017 & 2018 \\
\hline Deep ploughing & $23.2 b$ & $27.7 b$ & $27.4 b$ & $0.08 c$ & $0.16 c$ & $0.17 b$ \\
\hline Shallow ploughing & $19.7 b$ & $27.2 b$ & $29.9 b$ & $0.11 b c$ & $0.16 c$ & $0.23 b$ \\
\hline Deep cultivation & $27.4 b$ & $37.6 b$ & $36.1 b$ & $0.15 b c$ & $0.28 \mathrm{bc}$ & $0.30 \mathrm{~b}$ \\
\hline Shallow cultivation & $26.5 b$ & $33.8 \mathrm{~b}$ & $40.4 a b$ & $0.19 * a b$ & $0.39 * b$ & $0.55 * * a$ \\
\hline No-tillage (direct drilling). & $38.6 * a$ & $49.2^{* * a}$ & $50.0 * * a$ & $0.25 * * a$ & $0.61 * * a$ & $0.45 * * a$ \\
\hline $\mathrm{LSD}_{0.05}$ & 11.12 & 10.80 & 13.58 & 0.102 & 0.217 & 0.144 \\
\hline $\mathrm{LSD}_{0.01}$ & 15.59 & 15.15 & 19.03 & 0.144 & 0.304 & 0.202 \\
\hline
\end{tabular}

Similarly to our findings, Aschi et al. (2017) concluded, that Wheat-Beet-Faba Bean-Rape-Wheat rotation might promote microbial activities in agricultural soils. In fact, Siczek et al. (2018) found higher soil microbial activity in the rhizospheres of faba bean than in wheat.

\section{Earthworm abundance}

The abundance of earthworms in faba bean crops in Lithuania has not been determined at all, but it is clear that trends have remained similar to those of other crops. In the earlier field experiments of the Lithuanian scientists, the number of earthworms in ploughless plots increased by $23.4-53.4 \%$, and their biomass by $18.3-62.7 \%$ compared to deep ploughing (Stancevičius et al. 2003).

In our previous investigations, we have found that the reduction of primary tillage from conventional ploughing to shallow cultivation resulted in more or less similar number and mass of earthworms, but in NT plots the number of earthworms in the wheat stubble increased on the average by 2 and the mass by 3.7 times compared to DP plots (Romaneckas et al. 2016). In the current experiment of faba bean cultivation, the highest number of earthworms was found in NT plots, however the differences were mainly insignificant (Table 7). There, the biggest biomass of earthworms was also found, but the differences were significant in most cases as well.

We found that average temperatures during vegetative period (April-August) had higher impact on earthworm mass $(r=0.530$ at $p \leq 0.05)$ than precipitation rates $(r=0.321 p>0.05)$. Influence on the number of earthworm was weak.

Table 7. Effect of different tillage practise on number $\left(\mathrm{m}^{-2}\right)$ and fresh biomass $\left(\mathrm{g} \mathrm{m}^{-2}\right)$ of earthworms

\begin{tabular}{|c|c|c|c|c|c|c|}
\hline \multirow[t]{2}{*}{ Tillage system } & \multicolumn{2}{|c|}{2016} & \multicolumn{2}{|c|}{2017} & \multicolumn{2}{|c|}{2018} \\
\hline & number & biomass & number & biomass & number & biomass \\
\hline Deep ploughing & $133.3 b$ & $39.5 c$ & $81.5 a$ & $23.5 c$ & $90.2 a$ & $27.1 \mathrm{c}$ \\
\hline Shallow ploughing & 154.0ab & $60.0 \mathrm{bc}$ & $80.3 a$ & $42.9 c$ & $113.2 \mathrm{a}$ & $33.7 \mathrm{bc}$ \\
\hline Deep cultivation & $109.3 b$ & $72.0 * \mathrm{~b}$ & $82.5 a$ & $49.9 b c$ & $158.5 a$ & $63.1 * a$ \\
\hline Shallow cultivation & $81.0 \mathrm{~b}$ & $75.5^{* *} \mathrm{~b}$ & $69.8 a$ & $96.0 * * a b$ & $161.2 \mathrm{a}$ & $57.0 * a b$ \\
\hline No-tillage & $196.3 * a$ & $129.2 * * a$ & $119.5 a$ & $134.7 * * a$ & $156.5 a$ & $58.6 * a b$ \\
\hline $\mathrm{LSD}_{0.05}$ & 54.09 & 23.25 & 51.21 & 49.49 & 74.13 & 27.58 \\
\hline $\mathrm{LSD}_{0.01}$ & 75.83 & 32.59 & 71.79 & 69.38 & 103.92 & 38.66 \\
\hline
\end{tabular}

${ }^{*}=$ significant differences from the control treatment (DP) at $p \leq 0.05 ;^{* *}=$ at $p \leq 0.01$. Different letters within columns mean significant difference at $p \leq 0.05$.

\section{Grain yield}

Long-term tillage practise had insignificant influence on faba bean grain yield, except in obsoleted cases in 2018 (Table 4). Yield variation mainly depended on the differences in crop density (Romaneckas et al. 2017). 
In our previous investigations at the same base of experiment, we did not find any significant yield differences in many other agricultural crops (Romaneckas et al. 2006, Romaneckas et al. 2009, Avižienytė et al. 2013, Romaneckas et al. 2019). In contrast to our study, Badagliacca et al. (2018) found significant increase in the faba bean grain yield in not tilled plots, by $23 \%$ compared with conventional tillage (deep ploughing and harrowing).

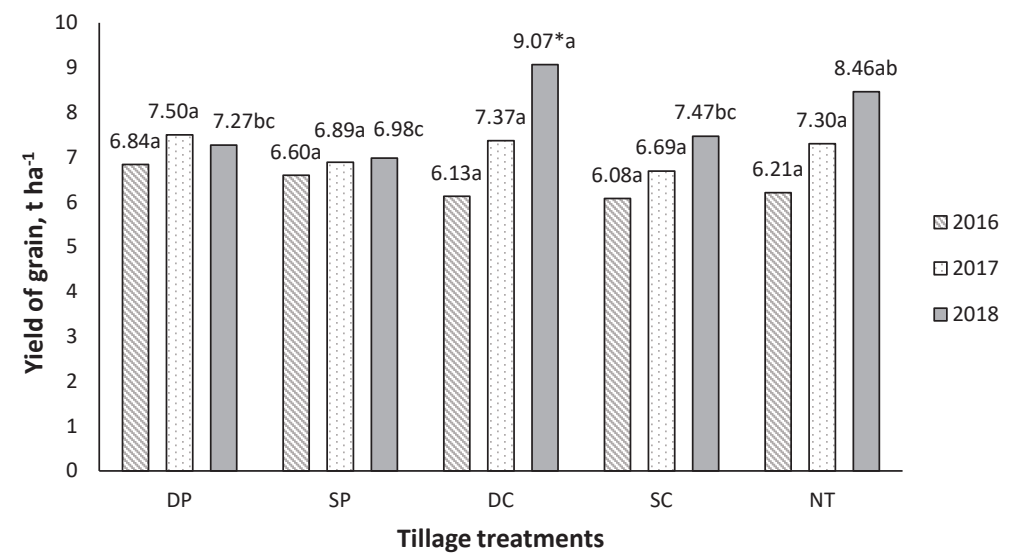

Fig. 4. Effects of different tillage practice on faba bean grain yield $\left(\mathrm{t} \mathrm{ha}^{-1}\right) .{ }^{*}=$ significant differences from the control treatment (DP) at $p \leq 0.05 ; * *=$ at $p \leq$ 0.01 . Different letters within columns mean significant difference at $p \leq 0.05$. DP = deep mouldboard ploughing (control treatment); $\mathrm{SP}=$ shallow mouldboard ploughing; $\mathrm{DC}=$ deep cultivation-chiselling; $\mathrm{SC}=$ shallow cultivation-disking; NT = no-tillage (direct sowing).

What regards to our experiment, differences of meteorological conditions had a greater and more significant impact (at $p \leq 0.05$ ) than tillage treatments. The average grain yield in the experiment was $7.12 \mathrm{t} \mathrm{ha}^{-1}$ and about $2 \mathrm{t}$ $\mathrm{ha}^{-1}$ higher than the average of Lithuanian farms. Similarly with our findings, Alarcón et al. (2018) in 9-year Spanish field investigations found, that annual meteorological variability had higher impact on yield of the legumes (pea and vetch) than the tillage systems. Arvidsson et al. (2014) concluded, that pea yields in shallowly non-inversely tilled plots were similar or slightly lower than in ploughed ones under Swedish conditions.

\section{Conclusions}

1. The greatest differences in soil penetration resistance were established before the pre-sowing tillage in spring. NT plots were those that hardened the most during wintering, but the differences in penetration resistance during vegetation were low, except in rainy 2017, when penetration resistance of NT plots remained the highest until the end of vegetation.

2. Reduced tillage intensity significantly increased soil aggregate stability to water. During the vegetation, the roots of faba beans influenced the increase in soil stability, which was most pronounced in the of 0-15 cm soil layer.

3. Substituting deep soil tillage with other alternatives has increased soil enzyme activity. Significantly highest enzyme activity was found in NT plots. The activity of saccharase was $0.7-2.0$ and urease was about 3-4 times higher than in the deeply ploughed control plots.

4. Significantly highest number and biomass of earthworms was found in NT plots. According to the average data, the number of earthworms in untreated plots was about $60 \%$, and their biomass was more than 3 times higher than in DP.

5. Differences of faba bean grain yield between long-term tillage treatments were insignificant. Yield varied more between vegetative seasons $(p \leq 0.05)$.

6. In general, reduced tillage practise could be an efficient way to stabilize soil properties and ensure high productivity of faba beans. 


\section{Acknowledgements}

Investigations were supported by a grant (No. MT-16-8) from the Ministry of Agriculture of the Republic of Lithuania.

\section{References}

Alarcón, R., Hernández-Plaza, E., Navarrete, L., Sánchez, M.J., Escudero, A., Hernanz, J.L., Sánchez-Giron, V. \& Sánchez, A.M. 2018. Effects of no-tillage and non-inversion tillage on weed community diversity and crop yield over nine years in a Mediterranean cereal-legume cropland. Soil \& Tillage Research 179:54-62. https://doi.org/10.1016/j.still.2018.01.014

Alvarez, R. \& Steinbach, H.S. 2009. A review of the effects of tillage systems on some soil physical properties, water content, nitrate availability and crops yield in the Argentine Pampas. Soil \& Tillage Research 104: 1-15. https://doi.org/10.1016/j.still.2009.02.005

Angers, D.A., Bullock, M.S. \&. Mehuys, G.R. 2006. Chapter 62, Aggregate Stability to Water. In: Carter, M.R. \& Gregorich, E.G. (eds.). Soil Sampling and Methods of Analysis. 2nd ed. USA: Canadian Society of Soil Science, CRC Press, Taylor \& Francis Group. p. 811-822.

Arvidsson, J., Etana, A. \& Rydberg, T. 2014. Crop yield in Swedish experiments with shallow tillage and no-tillage 1983-2012. European Journal of Agronomy 52: 307-315. https://doi.org/10.1016/j.eja.2013.08.002

Arvidsson, J., Westlin, A. \& Sörensson, F. 2013. Working depth in non-inversion tillage-Effects on soil physical properties and crop yield in Swedish field experiments. Soil \& Tillage Research 126: 259-266. https://doi.org/10.1016/j.still.2012.08.010

Aschi, A., Aubert, M., Riah-Anglet, W., Nélieu, S., Dubois, C., Akpa-Vinceslas, M. \& Trinsoutrot-Gattin, I. 2017. Introduction of Faba bean in crop rotation: Impacts on soil chemical and biological characteristics. Applied Soil Ecology 120: 219-228. https:// doi.org/10.1016/j.apsoil.2017.08.003

Avižienytė, D., Romaneckas, K., Pališkytė, R., Bogužas, V., Pilipavičius, V., Šarauskis, E., Adamavičienė, A. \& Vaiciukevičius, E. 2013. The impact of long-term reduced primary soil tillage on maize (Zea mays L.) productivity. Žemdirbystè -Agriculture 100: $377-382$. https://doi.org/10.13080/z-a.2013.100.048

Badagliacca, G., Benítez, E., Amato, G., Badalucco, L., Giambalvo, D., Laudicina, V.A. \& Ruisi, P. 2018. Long-term no-tillage application increases soil organic carbon, nitrous oxide emissions and faba bean (Vicia faba L.) yields under rain-fed Mediterranean conditions. Science of the Total Environment 639: 350-359. https://doi.org/10.1016/j.scitotenv.2018.05.157

Blanco-Canqui, H. \& Ruis, S.J. 2018. No-tillage and soil physical environment. Geoderma 326: 164-200. https://doi.org/10.1016/j. geoderma.2018.03.011

Bogunovic, I., Pereira,P., Kisic, I., Sajko, K. \& Sraka, M. 2018. Tillage management impacts on soil compaction, erosion and crop yield in Stagnosols (Croatia). CATENA 160: 376-384. https://doi.org/10.1016/j.catena.2017.10.009

Bogužas, V., Kairytė, A. \& Jodaugienė, D. 2010. Soil physical properties and earthworms as affected by soil tillage systems, straw and green manure management. Žemdirbystè-Agriculture 97: 3-14.

Cannell, R.Q. 1985. Reduced tillage in north-west Europe - A review. Soil \& Tillage Research 5: 129-177. https://doi.org/10.1016/01671987(85)90028-5

Chunderova 1973. Enzymatic activity of gleyic soils in North-West zone. Summary of dissertation, Tallinn, Estonia. 47 p. (in Russian).

Clapperton, M.J., Baker, G.H. \&. Fox, C.A. 2006. Chapter 34, Earthworms. In: Carter, M.R. \& Gregorich, E.G. (eds.). Soil Sampling and Methods of Analysis. 2nd ed. USA: Canadian Society of Soil Science, CRC Press, Taylor \& Francis Group. p. 436-437.

Giambalvo, D., Ruisi, P., Saia, S., Di Micel, G., Frenda, A.S. \& Amato, G. 2012. Faba bean grain yield, $N_{2}$ fixation, and weed infestation in a long-term tillage experiment under rainfed Mediterranean conditions. Plant and Soil 360: 215-227. https://doi. org/10.1007/s11104-012-1224-5

Guenet, B., Lenhart, K., Leloup, J., Giusti-Miller, S., Pouteau, V., Mora, P., Nunan, N. \& Abbadie, L. 2012. The impact of long term $\mathrm{CO}_{2}$ enrichment and moisture levels on soil microbial community structure and enzyme activities. Geoderma 170: 331-336. https://doi.org/10.1016/j.geoderma.2011.12.002

Hofmann, E. \& Schmidt, W. 1953. Über das Enzymsystem unserer Kulturböden. II. Urease. Biochemische Zeitschrift 324: 125127. (in German).

Hofmann, E. \& Seegerer, A. 1950. Der Fermentgehalt des Bodens als Maßstab seiner biologischen Aktivität. Biochemische Zeitschrift 321: 97. (in German).

Jankauskas, B., Jankauskienė, G. \& Fullen, M.A. 2008. Soil erosion and changes in the physical properties of Lithuanian Eutric Albeluvisols under different land use systems. Acta Agriculturae Scandinavica Section B - Soil and Plant Science 58: 66-76. https:// doi.org/10.1080/09064710701214379

Jensen, E.S., Peoples, M.B., Boddey, R.M., Gresshoff, P.M., Hauggaard-Nielsen, H., Alves, B.J.R. \& Morrison, M.J. 2012. Legumes for mitigation of climate change and the provision of feedstock for biofuels and biorefineries. A review. Agronomy for Sustainable Development 32: 329-364. https://doi.org/10.1007/s13593-011-0056-7

Juhola, S., Klein, N., Käyhkö, J. \& Schmid Neset, T.S. 2017. Climate change transformations in Nordic agriculture? Journal of Rural Studies 51: 28-36. https://doi.org/10.1016/j.jrurstud.2017.01.013

Karkanis, A., Ntatsi, G., Lepse, L., Fernández, J.A., Vågen, I.M., Rewald, B., Alsiṇa, I., Kronberga, A., Balliu, A., Olle, M., Bodner, G., Dubova, L., Rosa, E. \& Savvas, D. 2018. Faba bean cultivation - Revealing novel managing practices for a more sustainable and competitiveness European cropping systems. Frontiers in Plant Science 9: 1115. https://doi.org/10.3389/fpls.2018.01115

Karmakar, R., Das, I., Dutta, D. \& Rakshit, A. 2016. Potential effects of climate change on soil properties: a review. Science International 4: 51-73. https://doi.org/10.17311/sciintl.2016.51.73 
K. Romaneckas et al. (2019) 28: 101-111

Kazemi, H., Shahbyki, M. \& Baghbani, S. 2015. Energy analysis for faba bean production: A case study in Golestan province, Iran. Sustainable Production and Consumption 3:15-20. https://doi.org/10.1016/j.spc.2015.07.004

Kertész, Á. \& Madarász, B. 2014. Conservation Agriculture in Europe. International Soil and Water Conservation Research 2: $91-$ 96. https://doi.org/10.1016/S2095-6339(15)30016-2

Köpke, U. \& Nemecek, T. 2010. Ecological services of faba bean. Field Crops Research 115: 217-233. https://doi.org/10.1016/j. fcr.2009.10.012

López, M.V., Blanco-Moure, N., Limón, M.Á. \& Gracia, R. 2012. No tillage in rainfed Aragon (NE Spain): Effect on organic carbon in the soil surface horizon. Soil \& Tillage Research 118: 61-65. https://doi.org/10.1016/j.still.2011.10.012

Lozano-García, B. \& Parras-Alcántara, L. 2014. Changes in soil properties and soil solution nutrients due to conservation versus conventional tillage in Vertisols. Archives of Agronomy and Soil Science 60: 1429-1444. https://doi.org/10.1080/03650340.201 4.891731

Lukošiūnas, K. \& Germanas, L. 2006. Impact of tillage on soil agrophysical properties and bioactivity. Annals of Lithuanian University of Agriculture 38: 52-60.

Mikhailovskaja, N. \& Tarasčuk, E. 2008. Polyphenoloxidase and peroxidase activity in Luvisol loamy sand soil. In: Soil in sustainable environment. Proceedings of international conference. Kaunas-Akademija, Lithuania: Press of Lithuanian University of Agriculture. $47 \mathrm{p}$.

Moreira, W.H., Tormena, C.A., Karlen, D.L., daSilva, Á.P., Keller, T. \& Betioli Jr., E. 2016. Seasonal changes in soil physical properties under long-term no-tillage. Soil \& Tillage Research 160: 53-64. https://doi.org/10.1016/j.still.2016.02.007

Morris, N.L., Miller, P.C.H., Orson, J.H. \& Froud-Williams, R.J. 2010. The adoption of non-inversion tillage systems in the United Kingdom and the agronomic impact on soil, crops and the environment - a review. Soil \& Tillage Research 108: 1-15. https://doi. org/10.1016/j.still.2010.03.004

Ntatsi, G., Karkanis, A., Yfantopoulos, D., Olle, M., Travlos, I., Thanopoulos, R., Bilalis D., Bebeli, P. \& Savvas, D. 2018. Impact of variety and farming practices on growth, yield, weed flora and symbiotic nitrogen fixation in faba bean cultivated for fresh seed production. Acta Agriculturae Scandinavica, Section B-Plant Soil Science 38: 619-630. https://doi.org/10.1080/09064710.2018.1452286

Rasmussen, K.J. 1999. Impact of ploughless soil tillage on yield and soil quality. A Scandinavian review. Soil \& Tillage Research 53 : 3-14. https://doi.org/10.1016/S0167-1987(99)00072-0

Romaneckas, K., Adamavičienè, A., Sinkevičienè, A., Kimbirauskienė, R., Bogužas, V., Šarauskis, E., Butkus, V., Jasinskas, A., Buragienè, S. \& Čekanauskas, S. 2017. Influence of five tillage patterns on faba bean productivity parameters. In: Actual Tasks on Agricultural Engineering. Proceedings of 45 International Symposium on Agricultural Engineering. Opatija, Croatia: Press of University of Zagreb. p. 183-190.

Romaneckas, K., Avižienytè, D., Adamavičienè, A., Bogužas, V., Sinkevičienė, A., Šarauskis, E., Jasinskas, A., Kimbirauskienė, R., Balandaitè, J., Minajeva, A., Marks, M., Tyburski, J. \& Smanov, A. 2019. Impact of reduced tillage on spring oil seed rape, winter wheat, maize and spring barley production in Lithuania. In: Actual Tasks on Agricultural Engineering. Proceedings of 47 International Symposium on Agricultural Engineering. Opatija, Croatia: Press of University of Zagreb. p. 61-67.

Romaneckas, K., Avižienytė, D., Bogužas, V., Šarauskis, E., Jasinskas, A. \& Marks, M. 2016. Impact of tillage systems on chemical, biochemical and biological composition of the soil. Journal of Elementology 21: 513-526.

Romaneckas, K., Romaneckienè, R. \& Šarauskis, E. 2006. The effect of primary soil tillage methods on sugar beet growth on a light loam luvisol. Zemdirbyste-Agriculture 93: 81-87.

Romaneckas, K., Romaneckienè, R., Šarauskis, E., Pilipavičius, V. \& Sakalauskas, A. 2009. The effect of conservation primary and zero tillage on soil bulk density, water content, sugar beet growth and weed infestation. Agronomy Research 7: 73-86.

Romaneckas, K., Šarauskis, E., Avižienytė, D., Buragienè, S. \& Arney, D. 2015. The main physical properties of planosol in maize (Zea mays L.) cultivation under different long-term reduced tillage practices in the Baltic region. Journal of Integrative Agriculture 14: 1309-1320. https://doi.org/10.1016/S2095-3119(14)60962-X

Rusu, T., Moraru, P.I., Ranta, O., Drocas, I., Bogdan, I., Pop, A.I. \& Sopterean, M.L. 2011. No-tillage and minimum tillage - their impact on soil compaction, water dynamics, soil temperature and production on wheat, maize and soybean crop. Bulletin UASVM Agriculture 68: 318-323.

Sengar, R.S. \& Sengar, K. 2017. Climate change effect on crop productivity. 1st Edition. CRC Press, Taylor \& Francis Group. 538 p.

Soane, B.D., Ball, B.C., Arvidsson, J., Basch, G., Moreno, F. \& Roger-Estrade, J. 2012. No-till in northern, western and south-western Europe. A review of problems and opportunities for crop production and the environment. Soil \& Tillage Research 118: 66-87. https://doi.org/10.1016/j.still.2011.10.015

Siczek, A., Frąc, M., Kalembasa, S. \& Kalembasa, D. 2018. Soil microbial activity of faba bean (Vicia faba L.) and wheat (Triticum aestivum L.) rhizosphere during growing season. Applied Soil Ecology 130: 34-39. https://doi.org/10.1016/j.apsoil.2018.05.012

Stancevičius, A., Jodaugienė, D., Špokienè, N., Raudonius, S. \& Trečiokas, K. 2003. The influence of long-term ploughing and ploughless soil tillage on soil properties and spring barley crop. Žemdirbystè - Agriculture 83: 40-51.

Šarauskis, E., Buragienè, S., Masilionytè, L., Romaneckas, K., Avižienytė, D. \& Sakalauskas, A. 2014. Energy balance, costs and $\mathrm{CO}_{2}$ analysis of tillage technologies in maize cultivation. Energy 69: 227-235. https://doi.org/10.1016/j.energy.2014.02.090

Tao, J., Griffiths, B., Zhang, S.J., Chen, X.Y., Liu, M.Q., Hu, F. \& Li, H.X. 2009. Effects of earthworms on soil enzyme activity in an organic residue amended rice-wheat rotation agro-ecosystem. Applied Soil Ecology 42: 221-226. https://doi.org/10.1016/j.apsoil.2009.04.003

WRB 2014. World reference base for soil resources 2014. International soil classification system for naming soils and creating legends for soil maps. World Soil Resources Reports No. 106. FAO, Rome, Italy. 203 p. 